\title{
CONCEPÇÕES SOBRE RELAÇÕES AMOROSAS / CONJUGAIS E SOBRE SEUS PROTAGONISTAS: UM ESTUDO COM PROVÉRBIOS
}

\author{
Paulo Rogério Meira Menandro* \\ Rafaela Kerckhoff Rölke** \\ Milena Bertollo***
}

\section{RESUMO}

Os provérbios contêm informações culturalmente importantes sobre temas como casamento e relações de gênero, uma vez que constituem discurso autoritário e estereotipado aceito e memorizado pelas pessoas desde a infância. O presente estudo envolveu seleção e categorização de provérbios sobre relações amorosas, casamento, descasamento, bem como sobre as condiçôes socioculturais que caracterizam a vida masculina e feminina com o objetivo de analisar singularidades e regularidades reveladoras das concepções presentes em tal modalidade de produção cultural. A seleção dos 569 provérbios examinados foi feita a partir de fontes documentais. Os provérbios foram classificados em 4 grandes temas (Amor, Casamento e Relações Conjugais, Homem, Mulher) que comportaram 104 subcategorias de análise. Os resultados revelaram um universo cultural construído a partir da perspectiva masculina, no qual estão presentes concepçōes sobre a natureza feminina e sobre as relações amorosas que justificam o desequilíbrio de poder nas relações conjugais que se constata ainda hoje.

Palavras-chave: amor, casamento, relaçōes conjugais, gênero, provérbios

* Doutor em Psicologia. Professor Adjunto da Universidade Federal do Espírito Santo, no Departamento de Psicologia Social e do Desenvolvimento da Universidade Federal do Espírito Santo.

** Bolsista de Iniciação Científica CNPq - Universidade Federal do Espírito Santo.

*** Bolsista de Iniciação Científica CNPq - Universidade Federal do Espírito Santo. 


\begin{abstract}
CONCEPTIONS ABOUT CONJUGAL/ROMANTIC RELATIONSHIPS AND ABOUT THEIR PROTAGONISTS: A STUDY WITH PROVERBS

Proverbs contain culturally important information about themes such as marriage and gender relations, since they constitute an authoritarian and stereotyped discourse which is accepted and memorized by people from early ages. The present study involved selection and categorization of proverbs about romantic relationships, marriage, separation, as well as about the sociocultural conditions that characterize masculine and feminine life, with the objective of analyzing revealing singularities and regularities of the conceptions present in such modality of cultural production. The selection of the 569 examined proverbs was made from documental sources. The proverbs were classified in 4 broader themes (Love, Marriage and Conjugal Relations, Man, Woman) which spanned 104 analysis sub-categories. The results revealed a cultural universe constructed upon the male perspective, in which are found conceptions about the feminine nature and about romantic relationships that justify the unbalance of power in conjugal relationships still found in current days.

Keywords: love, marriage, conjugal relations, gender, proverbs
\end{abstract}

A importância das ações e reflexões dos seres humanos sobre os temas do amor e do casamento, no conjunto das relações sociais, é facilmente constatável, mesmo consideradas culturas ou épocas distintas. Tais ações e reflexões impregnam fortemente as diversas modalidades de produções culturais, como valores, princípios religiosos, normas, manifestações artísticas, linguagens e estereótipos. Entre tais produções culturais estão os provérbios que, no presente estudo, constituem a principal fonte de informações.

Obelkevich (1997), lembrando a limitação de registros documentais sobre a fala cotidiana de épocas passadas, assinala a alternativa adotada por folcloristas e antropólogos: estudar a fala a partir de formas e gêneros característicos (charadas, maldições, piadas, lendas, e similares). Diz ele: "Talvez a mais instrutiva delas sejam os provérbios; eles são tão antigos, têm sido amplamente usados, incorporam atitudes populares e [...] foram registrados em uma extensa linha de compilações impressas, que se inicia no século XVI" (Obelkevich, 1997: 44). Lauand (2000) propóe que o modo mais rápido de entender uma pessoa ou uma cultura seja aprender seus provérbios.

Apesar de os provérbios serem facilmente reconhecíveis, não é simples defini-los. Silva e Lomônaco (1995), citando Boesky, assinalam que a palavra grega gnome, que designa provérbio, também designa legendários homenzinhos que habitavam o interior da terra e guardavam seus tesouros, o que permite a analogia etimológica de que os provérbios encerram tesouros de sabedoria, guardados em 
sua forma condensada. Destacam ainda que o termo latino proverbium indica que uma expressão figurada é usada no lugar da palavra (pro verbo), ou seja, no lugar de algo que precisa ser dito.

Provérbios são ditos que se tornam parte das tradiçôes da cultura, com conteúdos que soam como conselhos sábios. Teixeira (2001: 194) diz que "eles são pensados como sendo expressão coletiva de sentimentos e entendimentos comuns e mesmo inerentes à vida sociocultural". Pode-se dizer que funcionam como consolidações de regras de comportamento e advertências a serem observadas. Fujikura (s/data) registra que o provérbio perpetua-se "na memória coletiva como modos de dizer tradicionais, cristalizados", em que a sabedoria popular exprime "sua experiência de vida [...] numa espécie de logaritmo sapiencial”, cujo propósito é apresentar "a conclusão tirada de numerosas e repetidas vivências, especialmente no campo das relações morais" (Fujikura, s/pág.). Lauand (2000, s/pág.) reconhece nos provérbios a condição de agentes privilegiados da educação invisível, já que "recolhem o saber popular, condensam a experiência sobre a realidade do homem: sua existência quotidiana, as condições de vida, o sensato e o ridículo, as alegrias e as tristezas, as grandezas e as misérias, a realidade e os sonhos, a objetividade e os preconceitos". Rónai (1985) observa que coletâneas de provérbios abrangem três tipos de enunciados: 1) expressões proverbiais ou maneiras de falar figuradas e metafóricas; 2) enunciações de fato ou verdade experimental que constatam uma maneira de agir ou de pensar comum a muitos; 3) ensinamentos morais ou conselhos práticos.

Obelkevich (1997) destaca que os provérbios, apesar de bastante usados na escrita, constituem gênero marcadamente oral que incorpora vários recursos retóricos. Os mais conhecidos são curtos e dão o recado rápida e incisivamente. "Metáfora, ritmo, aliteração, assonância, construções binárias: estes e outros recursos criam, na forma do provérbio, um eco do sentido" (Obelkevich, 1997: 44).

Para Rocha (1995: 170) os provérbios, entre as formas codificadas de linguagem, estão na mesma faixa dos lugares-comuns e automatismos que, "provenientes do código ideológico-cultural, instalam-se na língua que aprendemos desde a infância”. Mesmo com o uso continuado por longos períodos, eles permanecem sendo enunciados na forma original, como se fosse proibido modificá-la. Todavia, essa fixidez é essencial para a função que cumprem os provérbios, pois alterados a cada enunciação perderiam a característica de provir de sabedoria anônima e atemporal, sendo assim difícil de contestar, já que o enunciador original "é um ente inacessível, anônimo, perdido no tempo" (Rocha, 1995: 83). É possível que uma forma especialmente engenhosa contribua para preservar preconceitos, como nas alusões desqualificadoras da mulher em muitas culturas (Fujikura, s/data). 
Algumas compilações de provérbios exploram o fato de muitos deles serem comuns a vários idiomas, às vezes como traduçōes literais (por exemplo, Souza, 2001). Essa faceta de compartilhamento cultural relaciona-se ainda ao fato de os provérbios, mais que outras expressões literárias, incidirem sobre aquele núcleo permanente e atemporal da realidade do homem, o que permite acrescentar que, "por mais diversas que sejam as épocas, as latitudes ou as tribos, sempre encontraremos, essencialmente, pesadas críticas e ironias contra o egoísmo, a avareza, a inveja, a pequenez, etc e - invariavelmente também - o louvor da generosidade, da sinceridade, da grandeza, da lealdade" (Lauand, 2000, s/pág.).

Obelkevich (1997) registrou que a história dos provérbios na Europa foi marcada por oscilações entre os extremos da utilização difundida por vários segmentos sociais e de períodos de colapso geral na sua utilização em razão de mudanças na cultura letrada. Apesar de tal história de aceitação/rejeição, os provérbios são rica fonte de informação:

Se a vida social pode ser interpretada como um texto, muitas vezes é o provérbio ou a expressão trivial que fornece as pistas para essa leitura. Assim, para os historiadores preocupados com significados e mentalidades, os provérbios são uma fonte privilegiada, um ponto de entrada no domínio mais amplo do oral e das fórmulas. E para todos nós, imersos em material impresso (e expresso), superexpostos a livros, textos, escritos e escrituras, eles são o corretivo clássico: podemos lembrar-nos de que os provérbios "existiram antes dos livros" e "não são os livros, mas os velhos dizeres, que regulam a conduta humana" (Obelkevich, 1997: 74).

É interessante destacar, já que se falou de regular a conduta humana, que existem registros de culturas em que houve utilização de provérbios em contexto jurídico (Lacaz-Ruiz, 1988; Obelkevich, 1997).

Por outro lado, os provérbios não dizem tudo. Como adverte Obelkevich (1997), é possível que não conheçamos provérbios que tiveram circulação ampla em alguma cultura, mas que não mereceram registro impresso por serem especialmente grosseiros ou imorais, ou por enfatizarem perspectiva própria de grupos desprovidos de poder (o desequilíbrio entre provérbios de perspectivas feminina e masculina sobre alguns assuntos é exemplo). Além disso, provérbios de significados opostos coexistem em uma mesma cultura, principalmente quando referentes aos temas com as quais a cultura não lida sem conflito - casos de especial interesse para a pesquisa social. As questôes e limitações apontadas, contudo, não tornam inócuas investigaçôes apoiadas no exame de provérbios. 
Muitos provérbios sedimentados ao longo do tempo e intercambiados entre culturas referem-se ao amor, ao casamento e à sua dissolução, ao cotidiano conjugal e seus desdobramentos quanto a poder, interesse, enfado, traição, além do tema das características diferenciadoras de homem e mulher. Analisar provérbios sobre temas como casamento e relações de gênero pode revelar concepções interessantes sobre tais temas (que circularam ou que ainda sobrevivem), já que constituem discurso baseado em "estoque de estereótipos aceitos e memorizados" (Rocha, 1995: 140) pelos falantes de uma determinada cultura.

Falar de amor e casamento é falar de processos que sofreram transformaçôes no tempo, em especial no século XX, e os provérbios podem fornecer base apropositada para comparaçôes a respeito das concepçôes envolvidas em tais modificações.

Não encontramos estudos que lidaram com um conjunto amplo de provérbios sobre os temas aqui abordados. Ainda assim, é possível antecipar o conteúdo provável de alguns deles, conhecendo o teor de outras produções culturais sobre relaçôes amorosas e pelo exame de alguns provérbios de grande circulação. Obelkevich (1997) menciona ser comum, em provérbios europeus, a hostilidade em relação às esposas e às vezes à mulher em geral.

O presente texto relata investigação exploratória que envolveu análise de provérbios sobre relações amorosas, casamento, descasamento, assim como sobre as condiçôes socioculturais que caracterizam a vida masculina e feminina, visando interpretá-los e organizá-los em categorias temáticas, buscando singularidades e regularidades reveladoras das concepçōes presentes em tal modalidade de produção cultural.

\section{MÉTODO}

A seleção das afirmações foi feita a partir de compilações de provérbios (Souza, 2001; Lacerda, Lacerda e Abreu, 1999; Gomes, 1974; Mota, 1991; Magalhães Jr., 1977; Pandu, s/data; Masucci, 1958; Teixeira, 2004; Valle, 1997). Programas de busca na Internet proporcionam acesso a provérbios correntes em várias culturas (por exemplo: www.kocher.pro.br). Foi utilizado ainda material transcrito em estudos sobre provérbio ou sobre casamento (Obelkevich, 1997; Rocha, 1995; Jablonski, 1998; Campos, 2003).

Foram selecionados 616 provérbios. Alguns, além de conteúdos idênticos, apresentavam formas muito similares, e não foram considerados distintos, como: a1) Amor e tosse não dá pra esconder; a2) Amor e tosse a seu dono descobrem. Variações de mesmo conteúdo, mas com imagens diferentes, foram consideradas como 
afirmações distintas. Um exemplo: b) Paixão e sarna ninguém esconde; c) Tosse, amor e febre ninguém esconde. Desconsiderando-se aqueles provérbios quase idênticos, o número total somou 569 itens.

Material textual de qualquer natureza registra valores, normas, preconceitos, estereótipos, conflitos, atitudes, concepçôes ou representaçôes a respeito dos vários tipos de objetos, criaturas, símbolos, instituições, comportamentos, ocorrências e processos, que podem ser conhecidos a partir de análise de conteúdo clássica (Bauer, 2002). O trabalho fundamental ao lidar com os provérbios consistiu em criar categorias que os abrigassem de forma compreensível, tornando possível destacar concepções predominantes. $\mathrm{O}$ quadro resultante viabilizou a discussão de relações entre esses dizeres consolidados e aspectos contemporâneos das relações afetivas e conjugais.

\section{Resultados E Discussão}

Os 569 provérbios foram distribuídos por 4 grandes temas: A) Amor, englobando 152 provérbios; B) Casamento e Relaçôes Conjugais, compreendendo 230 provérbios; C) Homem, reunindo 36 provérbios; e D) Mulher, incorporando 149 provérbios. Outros dois provérbios não classificados somam-se a esses, como se verá mais à frente.

O grande tema Amor engloba provérbios que falam de qualquer aspecto das relações amorosas ou do sentimento do amor sem fazer menções específicas a casamento, marido, esposa, ou a algum aspecto identificável da vida conjugal.

No grande tema Casamento e Relaçôes Conjugais concentrou-se a maior quantidade e diversidade de provérbios. Eles mencionam o casamento como instituição; destacam aspectos cotidianos da relação conjugal; explicitam crendices relacionadas; ou abordam alguns outros temas que mereceram destaque por sua importância cultural, embora tenham sido pouco freqüentes. São temas como ciúme, traição, violência e diferença de idade.

O grande tema Homem reúne provérbios sobre características masculinas ou concepções de masculinidade que guardem alguma relação com a vida conjugal.

No grande tema Mulher foram classificados provérbios sobre características femininas ou sobre concepções de feminilidade relacionadas à vida conjugal. Uma diferença importante em relação ao grande tema Homem está no volume muito maior de provérbios incluídos e na diversidade de assuntos tratados.

No grande tema Amor os provérbios foram reunidos em uma só categoria chamada Sentimento de Amor e Relações Amorosas, com 21 subcategorias. Tais 
subcategorias estão relacionadas a seguir, com alguns provérbios vinculados às mais expressivas delas. Foram incluídos dois exemplos para cada uma das subcategorias nas quais foram classificados entre 6 e 12 provérbios e três exemplos para aquelas nas quais foram classificados 13 ou mais provérbios. Os exemplos foram escolhidos por um critério duplo: serem conhecidos e/ou especialmente representativos da concepção representada pela subcategoria em foco.

\section{A) SENTIMENTOS DE AMOR E RELAÇÕES AMOROSAS}

ab) Amor exige cuidados e encargos [12] Quem ama cuida / Quem ama Beltrão, ama seu cão

ac) Amor implica reciprocidade [8] Amor com amor se paga e com desdém se apaga / Amor é tempo perdido se não é correspondido

ad) Efemeridade do amor [8] $O$ amor faz passar o tempo e o tempo faz passar o amor / $O$ tempo rói o ferro, quanto mais o amor

ae) Exclusividade como componente do amor [6] Amor e senhoria não querem companhia / Amor e desconfiança não habitam a mesma casa

af) Força do amor [16] Amor e morte; nada é mais forte / Onde manda o amor não há outro senhor $/ O$ amor é a mais forte paixão porque ataca ao mesmo tempo a cabeça, o corpo e o coração

ag) Impossibilidade de esconder o amor [8] Tosse, amor e febre ninguém esconde / Paixão e sarna ninguém esconde

ah) Irracionalidade ou impossibilidade de certeza no amor [28] Quem ama o feio, bonito the parece / Amor e sabedoria fazem rara companhia / No amor e na medicina, nem sempre, nem nunca

aj) Sofrimento como característica do amor [16] Muito padece quem ama / Não há amor sem amargor / Quem bem te amar te fará chorar

au) Mística do primeiro amor [13] Amor primeiro, amor verdadeiro / Não há luar como o de janeiro, nem amor como o primeiro / Amor e bexiga só dá na gente uma vez

As demais subcategorias são: aa) Durabilidade do amor [5]; ai) Promessas de amor são duvidosas [3]; ak) Amor como experiência inevitável [2]; al) Amor é possível para todos, independentemente das características de cada um [4]; am) Amor pode ser substituído por outro amor [5]; an) Amor não pode ser substituído por outro amor [2]; ao) Distância compromete o amor [2]; ap) Distância não compromete o amor [5]; aq) Amor embota a visão, mas não totalmente [2]; ar) Relacionamento deve começar bem [1]; as) Importância do amor físico [5]; at) Amor à primeira vista é mais difícil de esquecer [1]. 
A análise dos provérbios contidos nas subcategorias acima mencionadas permite falar de cinco blocos de significados que organizam os conteúdos expressados. A concepção inicialmente mencionada é a de que o amor é uma experiência forte, não pode ser escondido, atinge a todos e pode ser duradouro (35 provérbios, em $a d, a f, a g, a k$ e $a l$.

Um segundo bloco de significados comporta as idéias de que, não obstante a força acima mencionada, o amor exige cuidados e impõe encargos, implica reciprocidade, pressupõe exclusividade (26 provérbios, em $a b, a c$ e $a e$ ).

No terceiro bloco, percebe-se, partindo dos elementos destacados nos blocos iniciais, que ainda assim: a) o amor é caracterizado pela irracionalidade ou imprevisibilidade; b) uma de suas características marcantes é o sofrimento ao qual fatalmente conduzirá, até por ser efêmero; c) eventualmente é fortalecido por brigas; d) envolve promessas duvidosas em seu processo de realização. É o bloco de significados de maior peso em relação ao grande tema Amor, expressados nas subcategorias ad, ah, ai e aj, somando 55 provérbios.

Esse sofrimento inevitável decorre parcialmente da realidade de nem sempre ser possível viver e consolidar um único amor, vivendo-o com plena significação e satisfação. A partir desse tema compreendem-se os vários provérbios sobre a mística e a pureza do primeiro amor, associados às idéias de que um amor não pode ser substituído por outro e de que nem mesmo a distância compromete a afeição (21 provérbios, em an, ap, at e au).

Completam o grande tema provérbios sobre aspectos práticos, que reconhecem que o amor depende de elementos objetivos (15 provérbios, em am, ao, aq, ar e as).

São escassos os provérbios que fazem o elogio do amor ou enaltecem a vivência desse sentimento. Como é característico dos provérbios serem admoestações ou conselhos, e não veículos de exaltação, isso é compreensível. Ainda assim, é importante destacar o predomínio de concepções de teor negativo, próximas do descrédito, que aconselham a desconfiar da experiência amorosa. Talvez se possa dizer que tais concepçôes, de forma coerente, preparam o terreno para as idéias comparáveis que se apresentam mais claras nos provérbios que falam da experiência conjugal, como se verá a seguir.

Provérbios sobre o grande tema Casamento e Relaçôes Conjugais constituíram sete categorias: A) Casamento [ou Noivado/Namoro] - como Instituição (18 subcategorias); B) Casamento - Relações Cotidianas (13); C) Casamento - Superstiçôes e Crendices (4); D) Ciúme (4); E) Traição (5); F) Violência (4); G) Diferença de Idade e Amor/Casamento (5).

Vale aqui justificar essa divisão do grande tema em sete categorias. É certo que as três categorias iniciais comportariam as demais: afinal, ciúme, traição e 
violência dizem respeito às relaçôes cotidianas, e a questão da diferença de idade diz respeito à instituição do casamento. Pela importância cultural dos temas interrelacionados do ciúme, da traição e da violência, entendeu-se que mereceriam descrição à parte. $\mathrm{O}$ tema da diferença de idade no casamento também foi descrito à parte por se diferenciar pelo tratamento quase sempre humorístico consignado nos provérbios.

Cada categoria comporta várias subcategorias, conforme descrito abaixo, mantendo-se o mesmo modo de identificar a quantidade de provérbios vinculados a elas, e citando-se exemplos para as mais expressivas nas mesmas proporçóes já mencionadas.

\section{B) CASAMENTO / NOIVADO / NAMORO - COMO INSTITUIÇÃO}

ba) Assimetria homem / mulher quando está em jogo o casamento [11] Casa teu filho quando quiseres e tua filha quando puderes / Mulher sem marido, barco sem leme

bb) Casamento exige certeza da escolha e deve ser decisão muito refletida [17] Antes que cases, olha o que fazes / Casa-te e verás: perdes o sono e mal dormirás / Casamento se desmancha até na porta da igreja

bc) Casamento como fim do amor e do bom relacionamento [15] $O$ noivo vai a cavalo e o arrependimento na garupa / $O$ amor é um sonho e o casamento é um despertador / $O$ casamento ensina a viver sozinho

bd) Casamento deve ocorrer entre pessoas semelhantes (homogamia) [10] Se queres bem casar, teu igual vai procurar / Coelho casa com coelha e não com ovelha

bi) Casamento é algo que sempre deve ser evitado [10] Quem pensa, não casa, nem faz casa / Se casar fosse bom, Cristo não teria morrido solteiro

As demais subcategorias são: be) Casamento deve ser indissolúvel [3]; bf) Casamento por imposição [2]; bg) Casamento por interesse visto negativamente [2]; bh) Casamento por interesse visto positivamente [3]; bj) Duração do noivado não pode ser longa [2]; bk) Preconceito ligado à idéia de casamento (ou de amor) [2]; bl) Casamento não exige oficialização [1]; bm) Aspectos da cerimônia de casamento [4]; bn) Investimento financeiro na cerimônia de casamento é grande [4]; bo) Ficar esperando casamento pode ser perda de tempo [2]; bp) Há uma idade adequada para casar [3]; bq) Casar é sempre a melhor opção, mesmo quando não há felicidade [2]; br) Não casar é melhor do que mal casar [1].

O exame dos provérbios sobre o casamento como instituição sugere classificação em quatro blocos de significados. No primeiro, é visada a desconfiança em relação à viabilidade do casamento. Agregados a tais provérbios estão aqueles que 
enfatizam que o casamento é o fim do amor e que, portanto, é um passo que deve ser evitado ou que deve ser precedido de muita reflexão para reduzir as chances de erro ( 43 provérbios, em $b b, b c, b i$ e $b r$ ). Embora tais provérbios, em sua maioria, sejam neutros em relação à orientação de gênero, entre aqueles que permitem constatá-la predominam concepçôes pensadas da perspectiva masculina: a) Casamento feito, noivo arrependido; b) Casa-se com uma mulher, vive-se com outra e ama-se só a nós mesmos; c) Melhor que casar com uma excelente mulher, só mesmo ficar solteiro; d) Um solteiro pode ser tão idiota quanto um homem casado, mas ele ouve isso menos vezes.

A diferença de gênero é clara no bloco de significados que reúne provérbios que explicitam a assimetria homem-mulher no âmbito do casamento. Há evidente hipocrisia sexista nos provérbios que admitem que as condiçôes relacionadas ao casamento impõem exigências distintas para homens e mulheres (11 provérbios, em $b a$ ). Além da ênfase na desvalorização da mulher sem marido (Três coisas são inúteis: rio que não tem água; terra que não tem rei; mulher que não tem marido), explora-se a certeza de que a filha precisa ser casada muito mais rapidamente do que o filho (Jerimum se guarda, mas melancia, se não comer logo, apodrece) e admite-se a assimetria até mesmo em questóes como a transmissão de herança (Ao filho a herança, à filha o dote).

O terceiro bloco de significados encerra a noção de homogamia: o casamento deve ocorrer entre pessoas semelhantes - socialmente, culturalmente e economicamente -, pois tal similaridade determinará do sucesso da relação (10 provérbios, em $b d$ ). É marcante na cultura brasileira a idéia de que o casamento ideal é homogâmico.

O quarto conjunto é um agrupamento heterogêneo de provérbios que se referem a temas diversos, sem destaques especiais. Engloba mençóes à cerimônia de casamento, ao casamento imposto, ao casamento por interesse, à idade adequada para casar. Vale destacar a escassez de mençōes à indissolubilidade do casamento: apenas 3 provérbios, e só um deles realmente convicto: $O$ que deus uniu, o homem não separe. Também só é mencionada em 2 provérbios a idéia de que o casamento é sempre a melhor opção, mesmo quando não há felicidade, tema que guarda relação com a questão de o casamento ser indissolúvel.

Está descrita, na sequiência, a categoria referente às relações cotidianas na vida conjugal, excetuando-se ciúme, traição e violência. São 14 as subcategorias:

\section{C) CASAMENTO / NOIVADO / NAMORO - RELAÇÕES COTIDIANAS}

cb) Feiúra da mulher e consequiências para o relacionamento [7] Sossego de homem é mulher feia e cavalo capado / Casa de mulher feia não precisa de tramela 
cf) Tarefas femininas que devem ser cumpridas [6] Mãe, que coisa é casar? Filha, fiar, parir e chorar / Mulher de janela, nem costura, nem panela

ch) Predomínio de poder / autoridade feminina visto como negativo [7] Não há paz onde canta a galinha e canta o galo / Mal vai a casa onde a roca manda mais que a espada

As demais subcategorias são: ca) Beleza não garante a continuidade do bom relacionamento [4]; cc) Casa e trabalho como providências essenciais para o casamento [3]; cd) Falta de dinheiro comprometendo a afeição ou o casamento [5]; ce) Intimidade não deve ser tornada pública [2]; cg) Pessoas de fora não devem interferir no relacionamento [4]; ci) Reconhecimento de que a autoridade principal é sempre a mulher [3]; cj) Sofrimento como característica do casamento por amor [1]; ck) Casamento por amor envolve lidar com coisas boas e ruins [1]; cl) Casamento como passo inicial para o amor [1]; cm) Doença forçando a continuidade do casamento [1].

Os provérbios acima relacionados podem ser classificados em quatro blocos de significados, todos sobre temas de natureza prática. O primeiro refere-se ao fato de que há tarefas bem definidas para as mulheres cumprirem na vida conjugal, cabendo aos homens a autoridade na relação. O poder feminino é visto negativamente. Alguns poucos provérbios registram que, em última análise, o poder é das mulheres, mas o fazem com um tipo de abordagem jocosa que explora a ambigüidade entre espaço público e mundo doméstico, no qual poderia ser exercido o poder feminino (16 provérbios, em $c f$, $c h$ e $c i$ ).

O segundo bloco temático destaca condições materiais (dinheiro, emprego, moradia) necessárias para a harmonia da relação (8 provérbios, em $c c$ e $c d$ ), contrapondo-se de forma desmistificadora à idéia de que a força do amor supera qualquer obstáculo.

No terceiro bloco de significados menciona-se a beleza ou a feiúra da esposa (11 provérbios, em $c a$ e $c b$ ). Predomina, no caso da beleza, a idéia de que ela não é suficiente para garantir a consolidação da relação. No caso da feiúra, brinca-se com o quase consolo de que o marido não deve temer a traição. Foi encontrado um provérbio comparável referindo-se ao homem, mas que caracteriza a mulher como interesseira (Homem rico nunca é feio).

A freqüência de menções às superstições e crendices em torno do casamento foi baixa. Foram consideradas apenas afirmaçōes classificadas como provérbios nas coletâneas examinadas (e em alguns casos tal classificação é duvidosa). Relações de superstições e crendices incluem muitas outras mençôes ao casamento que 
não são caracterizáveis como provérbios. Os resultados para tal categoria aparecem a seguir.

\section{D) CASAMENTO / NOIVADO / NAMORO - SUPERSTIÇŌES E CRENDICES}

da) Casamento é questão de acaso ou destino [8] Casamento e mortalha no céu se talha / Casamento é loteria

dd) Outros temas que envolvem superstição e casamento [7] Mulher que se casa em dia de Sant'Ana morre de parto / Quem se levantar primeiro da cama, no dia seguinte ao do casamento, é quem primeiro morre

As demais subcategorias são: $\mathrm{db}$ ) Ocorrências que determinam qualidade do relacionamento ou do casamento [5]; dc) Providências que levam ao casamento [1].

Um único tema está em jogo na categoria: trata-se da noção de que a adequação de parceiros e a qualidade do relacionamento conjugal é questão de sorte ou de destino. É possível que tal concepção relacione-se ao tema da irracionalidade e imprevisibilidade do amor (explorada em diversos provérbios). Considerando a história mais remota, é possível pensar que a idéia de sorte ou destino poderia ser vista como mais lógica ou coerente no contexto dos períodos em que o casamento era decidido a partir de interesses familiares, sem participação ativa e fundamentada no sentimento de amor dos casais diretamente envolvidos. É importante lembrar que a idéia de amor conjugal não se imporia como valor ideal do casamento senão em meados do século XIX (Vainfas, 1986).

O próximo conjunto de provérbios a ser comentado refere-se ao ciúme. São poucos provérbios, porém reveladores da ambigüidade que o assunto suscita.

\section{E) CIÚME}

As subcategorias relacionadas ao ciúme são: ea) Ciúme como componente inevitável do amor [5]; eb) Ciúme como algo que pode ser benéfico [1]; ec) Ciúme como algo que traz sofrimento [2]; ed) Ciúme como disfarce para outras coisas [4].

Como se percebe nos nomes das subcategorias, a ambigüidade é clara: destaca-se, por um lado uma idéia de ciúme como indicador do amor (Não há amor sem ciúme), como algo que pode ser benéfico e romântico (6 provérbios, em ea e $e b)$, ao mesmo tempo que é visto com uma certa faceta de falsidade, como no exemplo O ciúme depende mais da vaidade do que do amor, e como algo que leva ao 
sofrimento (6 provérbios, em ec e ed). É possível até mesmo falar de um tratamento que dá pouca importância ao ciúme, como no provérbio: Ciúmes mal fundados e mal pedidos parecem mais buscados que temidos.

Uma revisão de concepções de ciúme (Ramos, Yazawa e Salazar, 1994) mostra alguns elementos comuns: reação frente a uma ameaça percebida, em decorrência de um rival real ou imaginário, que objetiva eliminar os riscos de perda do amor. Apenas um dos provérbios sobre ciúme menciona gênero, falando de esposa, sugerindo que a admissão de ciúme por parte dos homens pode ter sido vista como inadequada culturalmente, talvez pela demonstração de fraqueza que revelaria. Situação similar revela-se nos provérbios (poucos) sobre traição: também esse assunto é tratado com ambigüidade e até com um certo descaso.

F) $\operatorname{TRAIÇÃO}$

fa) Traição feminina [8] O marido é sempre o último a saber / Mulher que a dois ama, a ambos engana

fb) Traição masculina [6] Cavalo peado também come / Homem não é pipoca, mas dá seus pulinhos

As demais subcategorias são: fc) Traição ignorada não é sentida [2]; fd) Desconfiança de traição compromete a relação [2]; fe) Reflexões sobre traição, independentemente de ser masculina ou feminina [3].

Provérbios sobre a traição feminina são especialmente neutros: apenas a constatam, sem julgá-la ou condená-la explicitamente. Provérbios sobre traição masculina também apenas a constatam, sem julgá-la, nem exaltá-la, o que seria possível em uma perspectiva machista. A ambigüidade de tratamento engloba até mesmo a hipocrisia ( $E$ melhor ser feliz do que saber a verdade) ou a ironia (Ama-se a traição, aborrece-se a traidor).

Nos provérbios sobre violência isso muda, uma vez que a ambigüidade desaparece.

\section{G) VIOLENNCIA}

ga) Justificativas da violência masculina [10] Pancada de amor não dói / Uma mulher pode amar um marido que nunca lhe bata, mas não vai respeitá-lo

As demais subcategorias são: gb) Justificativas da violência feminina [3]; gc) Interdição da violência masculina [2]; gd) Minimização da violência conjugal [1]. 
A idéia é a de que a mulher deve ser subjugada, ainda que com uso de violência. Só dois provérbios discrepantes foram encontrados: Numa mulher não se bate nem com uma flor e Pancadas espantam amores.

As poucas referências à violência da mulher contra o homem põem esse homem em situação ridícula, como nas afirmações Coices de égua, amor para rocim (rocim, no caso, designa cavalo fraco) e Quem apanha de mulher não se queixa a delegado. O provérbio Pancada de amor não dói, que é bastante conhecido, é o único integrante da subcategoria $g d$ e, embora não explicite a autoria masculina da violência, é quase sempre empregado com tal teor. A ridicularização de um tipo de homem também ocorrerá, e de forma categórica, nos provérbios sobre o tema da diferença de idade no amor ou no casamento.

\section{H) DIFERENÇA DE IDADE E AMOR / CASAMENTO}

ha) Velhice e dificuldade ou ridículo no amor [15] Marido velho e mulher nova, ou corno ou cova / Velho recém-casado, reza-lhe por finado / A mulher do velho reluz como o espelho

As demais subcategorias são: hb) Argumentos justificadores do casamento com homem mais velho [2]; hc) Argumentos justificadores do casamento com mulher mais velha [2]; hd) Homem mais velho como preferência para casamento [1]; he) Diferença de idade no casamento é garantia de filho [2].

O ponto chave em tais provérbios é a afirmação do ridículo que representa o velho enamorado ou casado com moça nova. Em vários provérbios insinua-se uma esperteza interesseira da mulher que participa dessa relação, revelando conteúdos desqualificadores da mulher e menções à traição feminina.

A análise dos provérbios referentes ao grande tema Homem sugere que trabalhar com 8 subcategorias (algumas idênticas às elaboradas para o grande tema Mulher) é suficiente para abranger a diversidade encontrada. Aparecem a seguir as subcategorias com a indicação da quantidade de provérbios pertinentes a cada uma, e com exemplos representativos nas mesmas proporções adotadas nas categorias anteriores.

\section{J) HOMEM}

ja) Homem casado fica esgotado e com a liberdade cerceada [6] Homem casado, burro estafado / A vida de solteiro é vazia, mas a de casado enche 
jc) Características indesejáveis no homem [12] Homem com fala de mulher, nem o diabo quer / Marido sem cuidado e casa sem telhado, de graça é caro

jf) Vulnerabilidade do homem [7] Três coisas enganam os homens: as mulheres, os copos pequenos e a chuva miúda / Homem é como lata, uma chuta, outra cata

As demais subcategorias são: jb) Características valorizadas de homem [2]; jd) Exigências para o homem casado [2]; je) Reputação duvidosa do homem religioso [2]; jg) Homem é enganador e dissimulado [4]; jh) Homem como enigma difícil de interpretar [1].

A relação mostra que foram poucos os provérbios localizados que mencionam o homem em aspectos relacionáveis com amor e vida conjugal. Diferentemente do que acontece em relação às mulheres, como se verá adiante, os provérbios não registram idéias de desqualificação dos homens, considerados como um todo. Alguns poucos provérbios destacam ser perigoso confiar nos homens: Jura de homem é riso de cão (em jg). Existem também provérbios que mencionam aspectos indicadores de vulnerabilidade (em $j f)$, no sentido dos homens estarem à mercê das mulheres, sempre apresentadas como enganadoras (Não há como a mulher para fazer do homem o quanto quer; Três coisas enganam os homens: as mulheres, os copos pequenos e a chuva miúda).

Outro aspecto destacado nos provérbios é o das características indesejáveis no homem e, complementarmente, mas com menor expressão, algumas características valorizadas (subcategorias $j b, j c$ e $j e$ ). A principal característica indesejável é óbvia: a falta de masculinidade, como nos provérbios que mencionam o homem com características afeminadas (Homem com fala de mulher nem o diabo quer).

Em uma subcategoria adicional o casamento é retratado como fardo que esgota o homem, além de o cercear (subcategorias ja e jd). São exemplos: Casarás, amansarás e te arrependerás; Homem casado, pássaro na gaiola. Tal visão masculina relaciona-se com os provérbios referentes ao casamento como instituição, que apregoam que casar exige certeza da escolha e deve ser decisão muito refletida ou, se possível, evitada.

Vários pontos assinalados a partir dos provérbios vistos até aqui são compreendidos com mais clareza quando se conhece o grande conjunto de provérbios sobre a mulher.

Da mesma forma que o grande tema Homem, o grande tema Mulher é abordado como uma única categoria. Diferentemente, no entanto, a categoria Mulher reuniu volume muito maior de provérbios em suas 14 subcategorias. As subcategorias e os respectivos exemplos aparecem a seguir, nas mesmas condições utilizadas nos demais grandes temas. 
K) MULHER

ka) Características desejáveis da mulher [11] Mulher honesta, ter o que fazer é a sua festar / Mulher honrada, em casa, de perna quebrada

kb) Características indesejáveis da mulher [24] Mulher de bigode nem o diabo pode I Da burra que faz "him" e da mulher que sabe latim, livra-te a tu e a mim I Mulher que não perde festa, pouco presta

kc) Falar demais ou fazer fofoca como característica feminina [18] Mulheres, quando se juntam a falar da vida alheia, começam na lua nova e acabam na lua cheia I Mulher de janela fala de todos, e todos dela / A boca de uma mulher nunca tira férias

kd) Desqualificação da mulher [17] Mulher, cachaça e bolacha em toda parte se acha / A mulher, o jogo e o vinho fazem errar o caminho / Homem de palha vale mais que mulher de ouro

ke) Exaltação da boa mulher [7] A mulher boa é prata que muito soa / Mulher boa, ave rara

kh) Mulher é enganadora e dissimulada [18] $A$ mulher e o vinho enganam o mais fino / Mulher, quanto mais fala, mais mente; quanto mais mente, mais jura I Lágrimas de mulher, têmpera de malícia

ki) Mulher objeto [9] Café, mulher e sopa, só quentes / Mulher é igual a circo, embaixo do pano é que está o espetáculo

kj) Características desvalorizadas que acompanham a beleza ou a vaidade da mulher [6] Moça louçã, cabeça vã / Mulher formosa, malvada ou preguiçosa

kk) Reputação da mulher é frágil e exige vigilância [19] A mulher e a galinha por andar se perdem asinha / Mulher, cavalo e cão, nem se emprestam nem se dão / Mulher é como espelho: pra se sujar basta o bafo

As demais subcategorias são: $\mathrm{kf}$ ) Mulher como enigma difícil de interpretar [4]; kg) Mulher consegue tudo [5]; kl) Reputação duvidosa da mulher religiosa [4]; km) Mulher está sempre interessada em posses [4]; kn) Formas de adestramento para lidar com a mulher [3].

O tema mais presente nos provérbios listados acima é o da desqualificação da mulher, que, de certa forma, está presente em todas as subcategorias, mas especialmente em $k c, k d, k g, k h$ e $k m$, somando 62 provérbios.

Em $k d$ a desqualificação é explícita sem mencionar alguma característica da mulher em especial (Do mar tira-se o sal e da mulher muito mal). Em alguns casos há comparação com o homem ( $A$ sombra de um homem vale mais que cem mulheres). 
Na subcategoria $k h$ a desqualificação resulta de as mulheres serem enganadoras e dissimuladas: Lágrimas de mulher valem muito e custam-lhe pouco; Não confie no céu de março mesmo que ele ria, não confie na mulher mesmo que ela chore.

A desqualificação, em $\mathrm{kg}$ e $\mathrm{km}$, relaciona-se ao fato de as mulheres serem interesseiras e engenhosas para atingirem seu intento: Amor de mulher, amor de cão, nada valem se nada lhe dão; Hábito de frade e saia de mulher, chega aonde quer.

A desqualificação retratada em $k c$ resulta da característica feminina de falar demais e fazer fofoca, como nos provérbios: Muitas mulheres, muitas palavras, muitos gansos, muito esterco; Segredo em boca de mulher é como manteiga em focinho de cachorro.

Outros 24 provérbios (classificados em $k b$ ) destacam características indesejáveis em uma mulher: ser masculinizada, mandona, exibida ou culta. No primeiro caso, a lógica é a mesma verificada para os homens: a mulher deve ser diferente dos homens em essência. $\mathrm{O}$ segundo envolve o poder masculino ameaçado pela mulher insubmissa, que pretende estar no comando. No terceiro, o tema da mulher que se expõe e se enfeita remete ao risco da traição. O último caso é específico do universo feminino: ser culta ou informada é um perigo pelo que tem de potencial subversivo, já que Mulher sabida é mulher perdida.

Considerando os provérbios arrolados até esse ponto, pode-se dizer que expressam parte das condiçôes culturais nas quais se consolidou a idéia da reputação de a mulher ser frágil e exigir vigilância e controle na relação conjugal, justificando o casamento em que a assimetria de poder é vista como natural, com o homem impondo as regras e exercendo a vigilância de seu cumprimento (19 provérbios, em $k k$ ). Em tal concepção, o espaço público diz respeito ao homem, devendo a mulher circunscrever-se ao mundo privado, ao mundo da casa, no qual servir ao marido deve lhe bastar.

Subjacente à desqualificação da mulher está a volubilidade feminina, a aptidão para ludibriar e iludir, ou, convenientemente, a facilidade com que a mulher pode ser enganada e ter sua reputação prejudicada. São argumentos que justificam impor limite, controle, jugo, uma vez que há risco iminente de traição feminina. A desqualificação constatada está de acordo com relato de outros autores, como Fujikura (s/data), quando menciona que várias culturas registram ditos com alusões sempre desdenhosas, depreciativas e desqualificadoras da mulher, ou como Obelkevich (1997), quando menciona ser corriqueira, em provérbios europeus, a hostilidade em relação às esposas e mesmo às mulheres em geral.

Por outro lado, existem provérbios (somam 7, em ke) que exaltam a boa mulher, sem precisar suas características, mas destacando que ela é rara. 
São reveladores os provérbios que destacam características desejáveis na mulher (11 provérbios, em $k a$ ). As qualidades femininas valorizadas condizem com as condições assimétricas "ideais" do casamento: ser honesta, trabalhadora, obediente, calada e caseira.

Vale mencionar ainda a existência de provérbios de tradição machista que se referem à mulher como objeto de consumo, mas que, paradoxalmente, revelam certo temor diante da beleza feminina (15 provérbios, em $k i$ e $k j$ ).

Fica claro que no ambiente cultural espelhado nos provérbios predomina a perspectiva masculina. Não é fácil precisar se os homens usam mais provérbios do que as mulheres no dia-a-dia, mas Obelkevich (1997: 48) registra que as evidências européias sugerem que sim, o que "condiz com a predisposição antifeminina nos próprios ditados”. Tal predisposição misógina pode ter vínculos com a proposição bíblica de Eva como criatura enganadora, instrumento da corrupção da inocência do povo de Deus. Como ressalta Goldschmidt (1998: 25), "o cristianismo foi orientado pela idéia de que a mulher causou a introdução do pecado no mundo e de que a sexualidade feminina provocava o pecado masculino", do que resulta ser vista no discurso teológico cristão como temível e dissimulada, justificando a necessidade de subordiná-la ao homem.

Do ponto de vista prático, concepções como as expressas nos provérbios subsidiaram a imposição de limites que, de forma geral, interditaram o acesso das mulheres aos direitos fundamentais para exercerem a cidadania: informação, educação, profissionalização, participação em instâncias decisórias, autonomia sobre seu próprio corpo. No âmbito das relaçôes conjugais, tais interdiçôes contribuíram decisivamente para o estabelecimento de assimetrias, dominaçōes e incontáveis formas de violência. Não é possível reconhecer nos provérbios uma imagem atualizada das relações sociais, das relações de gênero e das relações conjugais, mas é certo que muitas das concepções neles contidas afloram aqui e ali em acontecimentos contemporâneos. Rocha (1995) cita diversos provérbios usados em textos jornalísticos, discursos de campanha política e peças publicitárias atuais, no Brasil e na França, evidenciando sua vitalidade.

Os provérbios captaram o drama masculino da dificuldade, não obstante a condição dominante vivida pelo homem, de lidar com as incertezas e inseguranças relacionadas com o comportamento feminino e com os limites da subjugação da esposa na fronteira entre a paixão, o companheirismo e a quase escravidão. Mesmo a dupla moral sexual em privilégio do homem não elimina o risco da traição, da desonra social e da dúvida quanto à paternidade. Captaram também a solução que impregna nossa cultura ainda hoje: relaçôes conjugais marcadas pela subordinação, às vezes pela violência. 
Transformaçōes concretas na vida feminina e na conjugalidade, observadas a partir de meados do século $\mathrm{XX}$, ainda não estão expressas nos provérbios, que demandam tempo longo de consolidação, mas ressaltamos a localização de dois provérbios cujo teor já sinaliza aspectos inovadores: a) O que vale para o homem vale para a mulher, b) O trabalho do homem vai de sol a sol, o da mulher jamais se acaba.

Acreditamos que o exame dos provérbios trouxe contribuições ao conhecimento de concepções que estão na base da formação das práticas atuais. Seria interessante comparar tais concepções com aquelas encerradas em outras modalidades de produções culturais.

\section{REFERÊNCIAS BIBLIOGRÁFICAS}

Aguiar, S. (2004). Farmácia de pensamentos: medicina espiritual. Rio de Janeiro: Record. Bauer, M. W. (2002). Análise de conteúdo clássica: uma revisão. Em M. W. Bauer e G. Gaskell (Orgs.). Pesquisa qualitativa com texto, imagem e som: um manual prático (pp. 189-217). Petrópolis: Vozes.

Campos, A. L. A. (2003). Casamento e família em São Paulo colonial. São Paulo: Paz e Terra.

Fujikura, A. L. C. (sem data). "É loucura contar segredos às mulheres!" - Nota sobre a imagem da mulher nos provérbios de El Libro de Calila e Digna - retirado em 22/08/ 2005, em http://www.hottopos.com.br/notand4/loucmul.htm.

Goldschmidt, E. M. R. (1998). Convivendo com o pecado: na sociedade colonial paulista (1719-1822). São Paulo: Annablume.

Gomes, J. M. (1974). Nova recolha de provérbios e outros lugares comuns portugueses. Lisboa: Afrodite.

Jablonski, B. (1998). Até que a vida nos separe - a crise no casamento contemporâneo. Rio de Janeiro: Agir.

Lacaz-Ruiz, R. (1988). O referencial comum dos provérbios e a personalidade humana.

Em R. Lacaz-Ruiz. Projeto provérbios para escolas de primeiro e segundo graus (p. 50). São Paulo: Editora Mandruvá.

Lacerda, R. C.; Lacerda, H. R. C. e Abreu, E. S. (1999). Dicionário de provérbios - francês, português, inglês. Rio de Janeiro: Lacerda.

Lauand, L. J. (2000). Provérbios e educação moral - a filosofia da educação de Tomás de Aquino e a pedagogia do Mathal. Disponível em http://www.deproverbio.com/DPbooks /LAUAND/1.htm.

Magalhães Junior, R. (1977). Dicionário brasileiro de provérbios, locuções e ditos curiosos. Rio de Janeiro: Documentário. 
Masucci, F. (1958). Dicionário humorístico. São Paulo: Leia.

Mota, L. (1991). Adagiário brasileiro. Fortaleza: Banco do Nordeste.

Obelkevich, J. (1997). Provérbios e história social. Em P. Burke e R. Porter (Orgs.). História social da linguagem (pp. 43-81). São Paulo: Unesp.

Pandu, P. (sem data). Pensamentos sobre o amor. Rio de Janeiro: Ediouro.

Ramos, A. L. M.; Yazawa, S. A .K. e Salazar, A. F. (1994). Desenvolvimento de uma escala de ciúme romântico. Psicologia: teoria e pesquisa, 10 (3), 439-451.

Rocha, R. (1995). A enunciação dos provérbios - descrições em francês e português. São Paulo: Annablume.

Rónai, P. (1985). Dicionário universal Nova Fronteira de citaçôes. Rio de Janeiro: Nova Fronteira.

Silva, C. B. B. e Lomônaco, J. F. B. (1995). Elaboração e validação de um instrumento para avaliar tipos de pensamento através da interpretação de provérbios. Psicologia: teoria e pesquisa, 11 (1), 73-80.

Souza, J. R. (2001). Provérbios e máximas - coletânea de provérbios, máximas, sentenças e aforismos em sete idiomas. Rio de Janeiro: Lucerna.

Teixeira, N. C. (2004). A sabedoria condensada dos provérbios. Belo Horizonte: Leitura.

Teixeira, S. A. (2001). Produção e consumo social da beleza. Horizontes Antropológicos, 7 (16), 189-220.

Vainfas, R. (1986). Casamento, amor e desejo no Ocidente Cristão. São Paulo: Ática.

Valle, A. (1997). À noite todos os gatos são pardos (Antologia de Provérbios). Rio de Janeiro: Leo Christiano.

Recebido em 20 de setembro de 2005 Aceito para publicação em 30 de outubro de 2005 